\title{
Efektifitas Manajemen Produksi dalam Pengembangan Produk pada Usaha Industri Rumah Tangga Kue Kacang ljo KN Lumpia Sabang di Aceh Besar
}

\author{
Chairuni AR ${ }^{1}$, Wa Ode Al-Zarliani ${ }^{*}$ \\ UUniversitas Serambi Mekkah, Indonesia \\ 2Universitas Muhammadiyah Buton, Indonesia \\ "Korespondensi: waodealzarliani@yahoo.com
}

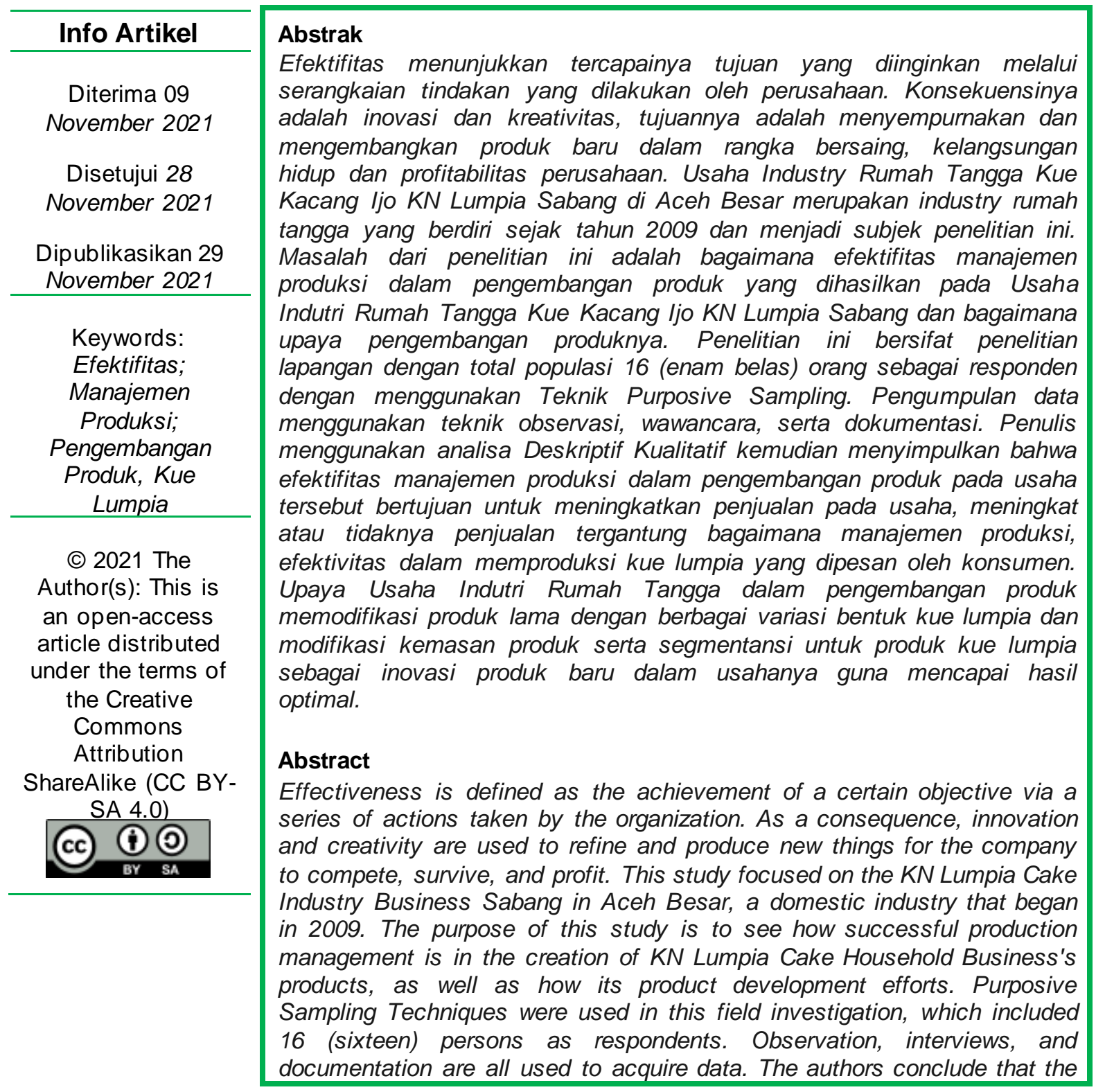




effectiveness of production management in product development in the
business aims to increase sales in the business, increase or not sales
depending on how production management, effectiveness in producing
lumpia cakes ordered by consumers, using Qualitative Descriptive
Analysis. To obtain the best outcomes, Household Industry Business
activities in product development alter previous goods with various kinds of
lumpia cakes, product packaging changes, and segmentation for lumpia
cake products as new product innovations.

\section{Pendahuluan}

Mendirikan sebuah perusahaan memerluan usaha yang gigih dan tidak mudah. Hal ini dikarenakan dalam menjalankan sebuah perusahaan memerlukan manajemen yang baik. Dalam mendirikan perusahaan harus mempounyai tujuan yang jelas apa output yang ingin dihasilkan. Perusahaan ataupun usaha yang didirikan tentunya disertai dengan harapan bahwa kelak dikemudian hari akan mengalami perkembangan yang pesat. Dalam proses mengembangkan perusahaan harus siap dengan berbagai risiko dan tantangan baik itu terkait dari segi manajemen, produksi maupun pemasaran (Fahdiansyah et al., 2018).

Suatu perusahaan dapat berkembang dengan pesat jika segala aspek dalam perusahaan mendukung keberhasilan perusahaan tersebut. Perusahaan dapat berkembang merupakan keinginan setiap individu yang berada didalam perusahaan tersebut, sehingga diharapkan dengan perkembangan tersebut perusahaan mampu bersaing dan mengikuti kemajuan jaman (Fahdiansyah et al., 2018).

Sistem manajemen yang baik adalah sebuah sitem yang akan menghunungkan dengan tujuan yang diinginkan. Managerial yang baik akan memudahkan terwujudnya tujuan perusahaan, karyawan dan masyarakat. Dengan manajemen, daya guna dan hasil guna unsur-unsur manajemen akan dapat ditingkatkan. Tujuan utama manajemen produksi adalah untuk menghasilkan barang dan jasa dengan kualitas yang tepat, jumlah yang tepat, pada waktu yang tepat dan dengan meminimumkan biaya untuk untuk meningkatkan efisiensi. Usaha/perusahaan yang efisien dapat menghadapi persaingan secara efektif. Manajemen produksi memastikan pemanfaatan penuh atau optimal dari kapasitas produksi yang tersedia (Thontowie et al., 2011).

Produksi adalah suatu kegiatan yang menghasilkan produk barang dan jasa. Kegiatan produksi akan menambah kegunaan dari masukan (input) menjadi keluaran (output). Dalam kegiatan tersebut dibutuhkan produksi dan operasi, yang melibatkan bahan baku, peralatan, dana serta tenaga sebagai faktor-faktor produksi diolah dengan proses teknologi tertentu untuk menghasilkan keluaran (output) dalam jumlah yang cukup besar (Sukoco et al., 2021).

Efektivitas dan efesiensi berperan penting dalam faktor produksi. Efektifitas dan efesiensi suatu produksi akan mewujudkan output yang diinginkan me menu hi target capaian tetapi ramah dari segi ekonomi. Sedangkan manajemen produksi adalah suatu aktifitas yang dilakukan oleh sekelompok manusia yang meliputi perencanaan, pengorganisasian, control serta pengarahan dengan cara yang efektif untuk mencapai suatu tujuan tertentu (Sangurjana et al., 2016). 
Perekonomian dalam suatu negara ataupun dalam suatu daerah terbentuk dari ribuan perusahaan atau usaha industri dalam menrancang suatu keberhasilan produksi dipoerlukan pemetaan yang jelas serta manjemen produksi yang matang sehingga produk yang kita inginkan berkualiats baik dalam perencanaan diperlukan hal-hal teknis terkait dengan pekerjaan itu agar mendapatkan hasil optimal (Thontowie et al., 2011).

Begitu pula dengan Usaha Industri Rumah Tangga Kue Kacang ljo KN Sabang yang merupakan sebuah usaha industry rumah tangga yang memproduksi kue lumpia. Peluang usaha lumpia prospeknya masih sangat cerah dan menjanjikan. Tergantung pada jumlah uang tunai yang tersedia, perusahaan ini dapat didirikan pada ukuran kecil, menengah, atau besar. Perusahaan ini dikelola dengan baik dengan manajemen sederhana, alat-alat manufaktur juga dasar, dan bahan baku mudah didapat dengan harga yang wajar. Usaha Industri Rumah Tangga Kue Kacang ljo KN Sabang, sebagai usaha yang memproduksi produk kue lumpia yang memiliki banyak competitor dengan tingkat harga jual bersaing ketat sehingga sangat membutuhkan pengembangan produk dalam proses produksinya.

Usaha pembuatan kue lumpia kacang ijo sudah berkembang di Kabupaten Aceh Besar, berdasarkan data Dinas Perindustrian Kabupaten Aceh Besar, terjadinya peningkatan untuk usaha industry rumah tangga kue lumpia sebesar $60 \%$ pada tahun 2020 dari tahun sebelumnya. Dari data tersebut tidak menutup kemungkinan terjadinya persaingan yang cukup signifikan dalam tingkat pemasaran kue lumpia kacang ijo ini. Dari hal tersebut juga sangat dibutuhkan manajemen produksi dalam pengembangan produk pada Usaha Industri Rumah Tangga Kue Kacang ljo KN Sabang untuk dapat bertahan dan atau memenangkan persaingan.

\section{Metode}

\subsection{Lokasi Penelitian}

Penelitian ini berlokasi di Jalan Laksamana Ajuen Kecamatan Peukan Bada Kabupaten Aceh Besar. Penentuan lokasi ini diterapkan secara sengaja (pu rposive sampling) dimana alasan penulis meneliti dilokasi ini dikarenakan usaha ini telah menjalani usahanya dengan berkelanjutan. Pelaksanaan penelitian ini berlangsung dari Bulan Agustus sampai September 2021.

\subsection{Subjek dan Objek Penelitian}

Adapun subjek dalam penelitian ini adalah pemilik usaha, pekerja dalam bidang produksi dan pekerja dalam bidang pemasaran/distribusi. Sedangkan objek penelitian ini adalah efektifitas manajemen produksi dalam pengembangan produk pada Usaha Industri Rumah Tangga Kue Kacang ljo KN Sabang Kabupaten Aceh Besar.

\subsection{Penentuan Responden}

Adapun responden yang telah ditentukan pada penelitian ini dilakukan yaitu 1 (satu) orang pemilik usaha, 10 (sepuluh) orang pekerja dalam bidang produksi dan 5 (lima) orang pekerja dalam bidang pemasaran/distribusi. Maka akumulasi responden sebanyak 16 (enam belas) orang. 


\subsection{Sumber Data Penelitian}

\section{a. Data Primer}

Data primer adalah informasi yang dikumpulkan oleh para peneliti langsung dari lapangan sehubungan dengan subjek yang sedang diselidiki.

\section{b. Data Sekunder}

Data sekunder adalah informasi yang diperlukan untuk mengumpulkan data penelitian, yang dapat berupa konsep atau informasi dari pihak ketiga yang terkait dengan hipotesis yang dapat digunakan untuk menjelaskan masalah.

\subsection{Metode Pengumpulan Data} termasuk:

Untuk membantu penelitian ini, berbagai jenis pengumpulan data digun akan,

a.pengamatan adalah tindakan melakukan pengamatan langsung di lapangan untuk mendapatkan gambaran yang benar tentang kegiatan yang sedang diperiksa::

b.wawancara yaitu dengan pemberlakuan tanya jawab langsung kepada responden berdasarkan pernyataan yang telah disusun dalam bentuk kuisioner.

c. dokumentasi merupakan berupa data dokumentasi dalam usaha seperti foto foto dan struktur organisasi dalam usaha tersebut.

\section{Pembahasan}

\subsection{Gambaran Umum Pendirian Usaha}

Usaha industri rumah tangga ini berdiri pada tahun 2009 dibawah pimpinan Bapak Usman. Berbekal pengalaman dan kemampuan dari tempat bekerja sebelumnya dalam membuat kue pia beliau membangun industri rumahan Usaha KN Lumpia Sabang. Beliau bertekat dengan usaha tersebut dapat berdampak positif terhadap perekonomian keluarga. Pada awal merintisusaha tersebut beliau bekerja sendiri, namun saat ini sudah mempunyai 16 orang tenaga kerja. Pada tahap awal segala kegiatan yang dilakukan dalam usaha ini dijalankan secara kecil-kecilan dengan menggunakan mesin-mesin berkapasitas rendah dikarenakan dalam proses penyesuaian. Setelah beberapa bulan produksi usaha ini menunjukkan adanya peningkatan yang cukup drastis serta peningkatan daya terima masyarakat yang baik sehingga produksi pun terus berkembang hingga sekarang. Usaha ini beroperasi dari jam $8.30 \mathrm{~s} / \mathrm{d} 14.30$ bertempat di Jln Laksamana Desa Ajun, Aceh Besar.

\subsection{Pengawasan Produk}

Pengawasan produksi sangat penting dilakukan dalam pengembangan produk dimana produk kue lumpia pada Usaha Industri Rumah Tangga KN Lumpia Sabang ini sudah teruji kehalalannya di LPPOM MPU ACEH dengan nomor 14200000020221 pada Tahun 2010 dan terdaftar di Departemen Kesehatan dengan nomor Dinkes PIRT No. 2061108010095-18. 


\section{3 Struktur Organisasi}

Manajemen memiliki kontak yang kuat dengan organisasi perusahaan atau perusahaan. Setiap perusahaan membutuhkan manajemen untuk memenuhi tujuannya dengan sukses dan efisien. Itu mengharuskan pengembangan struktu $r$ organisasi yang berfungsi sebagai alat manajemen dalam mengejar tujuan perusahaan.

Adapun struktur organisasi Usaha Industri Rumah Tangga Kue Kacang ljo KN Lumpia Sabang ini dapat dilihat pada bagan di bawah ini :

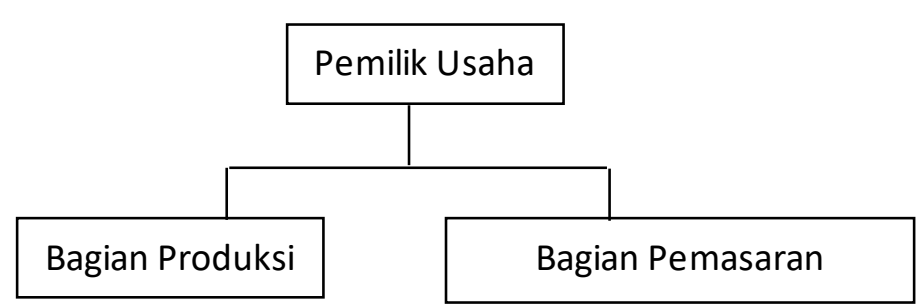

Gambar 1. Struktur Organisasi Usaha KN Lumpia Sabang

Dari Gambar 1 dapat dijelaskan bahwa terdapat pembagian kerja yang jelas dalam usaha ini, yaitu :

a. Pemilik Usaha bertanggungjawab penuh u ntuk keselu ruhan kegiatan usaha.

b. Bagian Produksi bertugas menjalankan proses produksi dengan menyeluruh sejak awal sampai akhir proses produksi sampai pada proses pengemasan.

c. Bagian Pemasaran bertugas menjalankan proses pemasaran atau distribusi yaitu pengantaran kue lumpia ke tempat-tempat penjualan/pelanggan.

\subsection{Efektifitas Manajemen Produksi}

Guna mengentahui bagaimana efektifitas manajemen produksi pada pengembangan produk pada Usaha Industri Rumah Tangga Kue Kacang ljo KN Lumpia Sabang di Aceh Besar ini, Para penulis mengumpulkan data menggunakan wawancara tanya jawab berdasarkan pertanyaan yang dihasilkan oleh para peneliti di lapangan. Penulis memberikan temuan jawaban responden kuesioner di beberapa tabel di bawah ini:

Tabel 1. Keterangan Responden Tentang Perencanaan Usaha

\begin{tabular}{ccc}
\hline $\begin{array}{c}\text { Tanggapan } \\
\text { Responden }\end{array}$ & Frekuensi & $\begin{array}{c}\text { Persentase } \\
(\%)\end{array}$ \\
\hline Sudah & 12 & $75 \%$ \\
\hline Kadang-kadang & 2 & $12,5 \%$ \\
\hline Belum & 2 & $12,5 \%$ \\
\hline Total & 16 & $100 \%$ \\
\hline
\end{tabular}

\section{Sumber : Data Olahan Hasil Penelitian}

Berdasarkan Tabel 1 menunjukkan bahwa Usaha KN Lumpia Sabang dalam melakukan kegiatan-kegiatan usahanya kerap didasarkan pada perencanaan yang jelas terukur, hal ini berdampak pada peningkatan penjualan. Berdasarkan tabel yang di atas bahwa korenponden memberikan jawaban sudah adalah berjumlah 12 orang (75\%). Kemudian yang mnejawab kadang hanya berjumlah 2 orang 
$(12,5 \%)$ serta yang menjawab belum berjumlah 2 orang $(12,5 \%)$ responden.

Untuk mengetahui tingkat poengetahuan responden tentang sistem organisasi usaha Usaha KN Lumpia Sabang peneliti memberikan kuisioner kepada perkerja. Hasil penelitian menunjukkan bahwa rata-rata responden mengatakan bahwa struktir orgsnisasi jelas disusun dengan baik. Hal tersebut dapat dilihat berdasarkan Tabel 2 di bawah ini:

Tabel 2. Keterangan Responden Tentang Sistem Pengorganisasian

\begin{tabular}{ccc}
\hline $\begin{array}{c}\text { Tanggapan } \\
\text { Responden }\end{array}$ & Frekuensi & $\begin{array}{c}\text { Persentase } \\
(\%)\end{array}$ \\
\hline Kurang Baik & - & 0 \\
\hline Baik & 12 & $75 \%$ \\
\hline Sangat Baik & 4 & $25 \%$ \\
\hline Total & 16 & $100 \%$ \\
\hline
\end{tabular}

\section{Sumber: Data Olahan Hasil Penelitian}

Pada Keterangan dalam Tabel 2 di atas dapat dijelaskan tentang sistem pengorganisasian telah tersusun baik sejumlah 12 orang $(75 \%)$, sedangkan yang menjawab sangat baik sejumlah 4 orang (25\%).

Berikut juga pendapat responden tentang manajemen produksi yang dijelaskan pada tabel berikut:

Tabel 3. Keterangan Responden Tentang Manajemen Produksi

\begin{tabular}{ccc}
\hline $\begin{array}{c}\text { Tanggapan } \\
\text { Responden }\end{array}$ & Frekuensi & $\begin{array}{c}\text { Persentase } \\
(\%)\end{array}$ \\
\hline Sangat Baik & 4 & $25 \%$ \\
\hline Baik & 11 & $68,75 \%$ \\
\hline Tidak Baik & 1 & $6,25 \%$ \\
\hline Total & 16 & $100 \%$ \\
\hline
\end{tabular}

\section{Sumber: Data Olahan Hasil Penelitian}

Dari Tabel 3 diatas yang menyatakan bahwa Usaha KN Lumpia Sabang jelas menciptakan manajemen produksi dengan baik. Pengolahan data tersebut berdasarkan koresponden yang menjawab baik sebanyak 11 orang $(68,75 \%)$ responden, kemudian yang menjawab sangat baik sejumlah 4 orang $(25 \%)$ responden serta yang menjawab tidak baik sejumlah 1 orang $(6,25 \%)$ responden.

Tabel berikut menunjukkan pandangan responden tentang bagaimana manajemen produksi telah berfungsi dengan sukses dan efisien.:

Tabel 4. Keterangan Responden Tentang Manajemen Produksi

\begin{tabular}{|c|c|c|}
\hline $\begin{array}{c}\text { Tanggapan } \\
\text { Responden }\end{array}$ & Frekuensi & $\begin{array}{c}\text { Persentase } \\
(\%)\end{array}$ \\
\hline Sudah & 12 & $75 \%$ \\
\hline Kadang-kadang & 3 & $18,75 \%$ \\
\hline Belum & 1 & $6,25 \%$ \\
\hline Total & 16 & $100 \%$ \\
\hline
\end{tabular}

Sumber : Data Olahan Hasil Penelitian

Pada keterangan 4 diatas yang menyatakan tentang berjalannya efektifitas serta efisiensi manajemen produksi sebanyak 12 orang (75\%) responden, kemudian yang menjawab kadang-kadang sejumlah 3 orang $(18,75 \%)$ responden 
dan yang menjawab belum sejumlah 1 orang $(6,25 \%)$ responden.

Selanjutnya, peneliti dapat ditunjukkan pada Tabel 5 di bawah ini untuk mengetahui jawaban responden mengenai upaya yang dipilih dalam pemilihan bahan baku untuk membuat kue lumpia:

Tabel 5. Keterangan Responden Tentang Usaha Selektif Dalam Pemilihan Bahan Baku

\begin{tabular}{ccc}
\hline $\begin{array}{c}\text { Tanggapan } \\
\text { Responden }\end{array}$ & Frekuensi & $\begin{array}{c}\text { Persentase } \\
(\%)\end{array}$ \\
\hline Sudah Selektif & 14 & $87,50 \%$ \\
\hline Kadang-kadang & 1 & $6,25 \%$ \\
\hline Belum Selektif & 1 & $6,25 \%$ \\
\hline Total & 16 & $100 \%$ \\
\hline
\end{tabular}

Sumber: Data Olahan Hasil Penelitian

Menurut Tabel 5, upaya telah selektif dalam pemilihan bahan baku seban yak 14 orang $(87,50 \%)$ responden, sedangkan yang menyatakan kadang-kadang sebanyak 1 orang $(6,25 \%)$ responden, dan mereka yang menyatakan belum dipilih oleh sebanyak 1 orang $(6,25 \%)$ responden. Bahan baku dipilih karena berbagai alasan., karena dalam proses produksi lumpia usaha ini menggunakan bahan yang berkualitas dan sudah teruji kualitasnya di laboratorium LPPOM.

Selanjutnya peneliti juga ingin mengetahui terdapatnya pengawasan dalam menentukan tindakan pada perusahaan dapat dilihat pada tabel berikut:

Tabel 6. Keterangan Responden Tentang Adanya Pengawasan Dalam Mengambil Tindakan

\begin{tabular}{ccc}
\hline $\begin{array}{c}\text { Tanggapan } \\
\text { Responden }\end{array}$ & Frekuensi & $\begin{array}{c}\text { Persentase } \\
(\%)\end{array}$ \\
\hline Ada & 14 & $87,50 \%$ \\
\hline $\begin{array}{c}\text { Kadang-kadang } \\
\text { Ada }\end{array}$ & 2 & $12,50 \%$ \\
\hline Tidak Ada & 0 & $0 \%$ \\
\hline Total & 16 & $100 \%$ \\
\hline
\end{tabular}

Sumber: Data Olahan Hasil Penelitian

Dari keterangan diatas yang menyatakan terdapatnya pengawasan pada pengambilan tindakan korektif dalam menjalankan operasi usaha sebanyak 14 orang $(87,50 \%)$ responden.

\subsection{Pengembangan Produk}

Dalam hal pengembangan produk penulis ingin mengetahui tanggapan responden tentang upaya pengembangan produk yang dilakukan Usaha KN Lumpia Sabang. Hasil uji kuionioner dapat dilihat sebagai berikut:

Tabel 7. Keterangan Responden Tentang Usaha Melakukan Diversifikasi Produk Sebagai Salah Satu Upaya Dalam Pengembangan Produksi

\begin{tabular}{ccc}
$\begin{array}{c}\text { Tanggapan } \\
\text { Responden }\end{array}$ & Frekuensi & $\begin{array}{c}\text { Persentase } \\
(\%)\end{array}$ \\
\hline Ya & 15 & $93,75 \%$ \\
\hline Belum & 1 & $6,25 \%$ \\
\hline Tidak & 0 & $0 \%$ \\
\hline
\end{tabular}




\begin{tabular}{ccc}
\hline Total & 16 & $100 \%$ \\
\hline
\end{tabular}

Sumber: Data Olahan Hasil Penelitian

Berdasarkan keterangan diatas dapat disimpulkan bahwa Usaha KN Lumpia Sabang telah melakukan diversifikasi produk sebagai upaya pengembangan produk dimana yang menjawab "Ya" sejumlah 15 orang $(93,75 \%)$ responden, kemudian yang menjawab "Belum" sejumlah 1 orang $(6,25 \%)$ responden. Kemudian tanggapan yang ingin diketahui oleh peneliti tentang upaya usaha gu na sebagai pemenuhan kepuasan konsumen dengan perbaikan tingkat kualitas produk dapat dilihat pada tabel berikut:

Tabel 8. Keterangan Responden Tentang Upaya Usaha Dalam Memenuhi Kepuasan Pelanggan Dengan Memperbaiki Tingkat Kualitas Produk

\begin{tabular}{ccc}
\hline $\begin{array}{c}\text { Tanggapan } \\
\text { Responden }\end{array}$ & Frekuensi & $\begin{array}{c}\text { Persentase } \\
(\%)\end{array}$ \\
\hline Ada & 14 & $87,50 \%$ \\
\hline Belum Ada & 2 & $12,50 \%$ \\
\hline Tidak Ada & 0 & $0 \%$ \\
\hline Total & 16 & $100 \%$ \\
\hline
\end{tabular}

Sumber: Data Olahan Hasil Penelitian

Berdasarkan keterangan tersebut disimpulkan bahwa Usaha KN Lumpia Sabang guna pemenuhan kepuasan pelanggan dengan memperbaiki kualitas produk, dimana yang menjawab "Ada" sejumlah 14 orang $(87,50 \%)$ responden, kemudian yang menjawab "Belum Ada" 2 orang (12,50\%) responden.

Tanggapan responden perihal efektifitas manajemen produksi terhadap Usaha KN Lumpia Sabang terhadap pengembangan produk dalam meningkatkan pendapatan usaha, dapat dilihat pada tabel berikut:

Tabel 9. Keterangan Responden Tentang Efektifitas Manajemen Produksi Terhadap Pengembangan Produk

\begin{tabular}{ccc}
\hline $\begin{array}{c}\text { Tanggapan } \\
\text { Responden }\end{array}$ & Frekuensi & $\begin{array}{c}\text { Persentase } \\
(\%)\end{array}$ \\
\hline Sangat Baik & 6 & $37,50 \%$ \\
\hline Baik & 10 & $62,50 \%$ \\
\hline Tidak Baik & 0 & $0 \%$ \\
\hline Total & 16 & $100 \%$ \\
\hline
\end{tabular}

\section{Sumber: Data Olahan Hasil Penelitian}

Dari Tabel 9 dapat dijelaskan bahwa tanggapan responden terhadap efektifitas manajemen produksi dalam pengembangan produk pada Usaha KN Lumpia Sabang adalah dimana sebanyak 6 orang $(37,50 \%)$ responden menyatakan sangat baik dengan alasan bahwa usaha terus mengalami peningkatan jumlah produksi dari waktu ke waktu secara kontinyu. Sedangkan sebanyak 10 orang $(62,50 \%)$ responden menyatakan baik terhadap efektifitas manajemen produksi kepada mengembangkan produk Usaha KN Lumpia Sabang, dengan alasan usaha ini telah melakukan diversifikasi produk dan segmentasi produk dalam segi ukuran dan bentuk kue lumpia yang mana hal tersebut dilakukan untuk dapat bertahan dan atau memenangkan persaingan. 


\subsection{Upaya Usaha KN Lumpia Sabang dalam Pengembangan Produk}

Selama tahap produksi usaha sangat selektif dalam pemilihan bahan baku, sebab dalam pengolahan kue lumpia menggunakan bahan baku yang berkualitas dan telah lulus uji kualitas di laboratorium LPPOM.

Usaha KN Lumpia Sabang berupaya Membantu karyawan dalam mewujudkan janji-janji yang sangat baik dan komunikasi antara pemilik bi sn is dan karyawan lain, di mana mereka adalah tim yang memiliki andil dalam kegiatan pekerjaan sehari-hari mereka. Hal ini dilakukan untuk mewujudkan strategi dan teknik manajemen produksi untuk mencapai hasil terbaik.

\section{Kesimpulan}

Efektifitas manajemen produksi pada Usaha KN Lumpia Sabang sudah berjalan dengan baik. Hal ini dapat dilihat dari pemahaman dan penilaian karyawan terhadap KN Lumpia Sabang sangat baik. Upaya dalam pengembangan sudah baik sehingga sampai saat ini terus bertahan dan memenangkan persaingan. Hal ini dapat terlihat dengan adanyaupaya KN Kue Lumpia Sabang untuk meningkatkan kualiatas produk dengan cara menjaga kualiats produk dan memperbaiki kinerja usaha dengn metode man ajemen produksi yang baik.

\section{Daftar Pustaka}

Dinas Perindustrian Kabupaten Aceh Besar (2020). Data Tahunan Jumlah Usaha Industri Rumah Tangga Kue Lumpia Kabupaten Aceh Besar.

Fahdiansyah, R., Qudsi, J., \& Bachtiar, A. (2018). Struktur Kepemilikan Dan Nilai Perusahaan: (Studi Pada Perusahaan Manufaktur Yang Listing Di Bursa Efek Indonesia). Jurnal VARIAN, 1(2), 41-49. https://doi.org/10.30812/varian.v1i2.70

Sangurjana, I. G. W. F., Widyantara, I. W., \& Dewi, I. A. L. (2016). Efektivitas dan Efisiensi Penggunaan Faktor Produksi Usahatani Cabai Besar di Desa Baturiti Kecamatan Baturiti Tabanan. Agrowisata, Jurnal Agribisnios Dan, 5(1), 1-11.

Sukoco, I., Fordian, D., Fauzan, F., \& Kurniawati, L. (2021). Penyuluhan makanan, bisnis kuliner, dan sertifikasi halal bagi pelaku ukm kabupaten pangandaran. Kumawu, 4(2), 344-352.

Thontowie, Septenaria, \& Riswan. (2011). Sistem pengendalian manajemen produksi dan hubungannya dengan pengelolaan persediaan bahan baku. Jurnal akuntansi\&keuangan, 2(july), 1-7.

Fahdiansyah, R., Qudsi, J., \& Bachtiar, A. (2018). Struktur Kepemilikan Dan Nilai Perusahaan: (Studi Pada Perusahaan Manufaktur Yang Listing Di Bursa Efek Indonesia). Jurnal VARIAN, 1(2), 41-49. https://doi.org/10.30812/varian.v1i2.70

Sangurjana, I. G. W. F., Widyantara, I. W., \& Dewi, I. A. L. (2016). Efektivitas dan Efisiensi Penggunaan Faktor Produksi Usahatani Cabai Besar di Desa Baturiti Kecamatan Baturiti Tabanan. Agrowisata, Jurnal Agribisnios Dan, 5(1), 1-11.

Sukoco, I., Fordian, D., Fauzan, F., \& Kurniawati, L. (2021). Penyuluhan makanan, bisnis kuliner, dan sertifikasi halal bagi pelaku ukm kabupaten pangandaran. Kumawu, 4(2), 344-352. 
Sugiyono. 2017. Metode Penelitian Kuantitatif, Kualitatif, dan R \& D. Bandung : CV. Alfabeta. Hal 334

Thontowie, Septenaria, \& Riswan. (2011). Sistem Pengendalian Manajemen Produksi dan Hubungannya dengan Pengelolaan Persediaan Bahan Baku. Jurnal Akuntansi\&Keuangan, 2(July), 1-7. 